\title{
Nitrogenase Activity and Oxygen Sensitivity of the Paspalum notatum-Azotobacter paspali Association
}

\author{
By JOHANNA DÖBEREINER*, J. M. DAY AND P. J. DART \\ Soil Microbiology Department, Rothamsted Experimental Station, \\ Harpenden, Hertfordshire
}

(Accepted for publication I I January 1972)

\begin{abstract}
SUMMAR Y
Nitrogenase activity in the rhizosphere of a grass, Paspalum notatum, and its associated soil was measured by the reduction of acetylene. Roots of the cultivar 'batatais' colonized by Azotobacter paspali, when taken from the soil, produced I to $32 \mathrm{nmol} \mathrm{C}_{2} \mathrm{H}_{4} / \mathrm{g}$ dry $\mathrm{wt} / \mathrm{h}$, whereas the cultivar 'pensacola', which is not colonized by $A$. paspali, produced less than $0.5 \mathrm{nmol} / \mathrm{g} / \mathrm{h}$. There was a lag of I 2 to $24 \mathrm{~h}$ before maximum, linear, rates of acetylene reduction were reached. Activity was almost completely inhibited in air or in the absence of $\mathrm{O}_{2}$ and was greatest at around $\mathrm{pO}_{2} 0.04 \mathrm{~atm}$. Activity of soil cores containing plants with leaves attached was little affected by $\mathrm{pO}_{2}$ and showed no lag. Soil-plant cores maintained in a $\mathrm{I} 6 \mathrm{~h}$ day $+8 \mathrm{~h}$ night showed no diurnal fluctuation in activity; as the dark period was extended, activity decreased but was restored on returning plants to the light. Roots and rhizomes had most activity, the soil very little and aerial parts none. Washing the roots removed less than half the activity. Disturbance of soil-plant cores decreased activity. The soil next to the root surface contained most $\boldsymbol{A}$. paspali; more were associated with active plants than with less active plants. Sections of roots showed abundant bacteria adjacent to the root surface. Nitrogen fixation by the association was estimated to be up to $90 \mathrm{~kg} \mathrm{~N} / \mathrm{ha} / \mathrm{annum}$.
\end{abstract}

\section{INTRODUCTION}

The sensitivity and convenience of the acetylene reduction technique as an assay of nitrogenase activity has stimulated work on the contribution of free-living nitrogen-fixing bacteria to the nitrogen cycle, and significant nitrogen gains to the ecosystem from these sources have been estimated (Pacewiczowa, Balandreau \& Dommergues, 1970; Steyn \& Delwiche, I970; Brouzes, Mayfield \& Knowles, I97I). Substantial nitrogenase activity in the rice rhizosphere has recently been reported (Rinaudo, 1970; Weinhard, Balandreau, Rinaudo \& Dommergues, I97I; Yoshida \& Ancajas, 197I) and azotobacter and other free-living nitrogen-fixing bacteria are thought to contribute significantly to the fertility of Egyptian soils (Abd-el-Malek, I97I). Our paper reports the potential nitrogen fixation of the specific association of Azotobacter paspali with Paspalum notatum, a subtropical grass widely distributed in South America (Döbereiner \& Campelo, 1971).

In the field Azotobacter paspali becomes permanently established in the rhizosphere of four tetraploid cultivars of Paspalum notatum, but not in the rhizosphere of other, mostly diploid, cultivars or other Paspalum species, even when artificially inoculated (Döbereiner, 1966, 1968, 1970; Kass, 1970; Döbereiner \& Campelo, 1971). Attempts to demonstrate nitrogen fixation after inoculating initially sterile sand cultures of $P$. notatum failed because

* Present address: Instituto de Pesquisas e Experimentacao Agropecuarias, Centro Sul, Rio de Janeiro, Brazil. 
$A$. paspali did not establish in the rhizosphere under these conditions (J. Döbereiner \& G. L. S. Peixoto Silva, unpublished data; Kass, 1970; Kass, Drosdoff \& Alexander, 1971). Pure cultures of $A$. paspali grow and fix nitrogen readily in nitrogen-free media (Döbereiner, 1970).

The partial pressure of oxygen affects nitrogen fixation and nitrogenase activity of Azotobacter chroococcum (Dalton \& Postgate, 1969a, b; Drozd \& Postgate, 1970a, $b$ ) and A. vinelandii (Parker \& Scutt, 1960). Bacteria grown in low $\mathrm{pO}_{2}(0.09 \mathrm{~atm})$ have maximum nitrogenase activities at a $\mathrm{pO}_{2}$ of 0.05 atm (Drozd \& Postgate, 1970 $b$ ) and carbon-limited cultures are even more sensitive to oxygen tension (Dalton \& Postgate, I969a). We examined the effect of oxygen tension on the amount of acetylene reduced by field-established associations of $A$. paspali and Paspalum notatum.

\section{METHODS}

Paspalum notatum cultivar. 'batatais' was obtained from sitesin long-established lawns or pastures of the Instituto de Pesquisas e Experimentacao Agropecuarias do Centro-Sul, $80 \mathrm{~km}$ south-west from Rio de Janeiro, Brazil. Sites A, B, C, E, F and I were different areas of an extremely sandy, grey hydromorphic soil in which crops often show manganese toxicity, site $D$ on a hydromorphic clay soil and sites $G$ and $H$ on a red-yellow podsol with sandy loam texture.

The plants were flown to Rothamsted Experimental Station in polyethylene bags kept over ice and were assayed within $48 \mathrm{~h}$ of harvest. Batches of plants (numbered I to 6) were received between October 1970 and January 1971 and, for the first four batches, roots were shaken free from soil before they were put into the plastic bags. Batches 5 and 6 were plants in undisturbed soil-cores in 11 metal cans (diam. $0.1 \mathrm{~m}$ ). These were placed in a heated glasshouse (temperature range 15 to $30^{\circ} \mathrm{C}$ ) at Rothamsted with a $16 \mathrm{~h}$ day maintained by $\mathrm{Hg}$ vapour lamps giving $10000 \mathrm{~lx}$ at plant level, for I to 4 weeks before assay.

For batches I to 4 nitrogenase was assayed on rhizomes and roots shaken free from loose soil. The rhizomes were cut into I $\mathrm{cm}$ long pieces with attached roots and adhering surface soil, and three to six pieces were placed in $28 \mathrm{ml}$ McCartney vials with moist filter paper added to keep the atmosphere saturated with water and the vials stoppered with Suba-Seals. The vials were evacuated to $40 \mathrm{mmHg}$ and flushed twice with $\mathrm{Ar}$, some Ar was then removed by syringe from the vial and replaced with an equivalent volume of $\mathrm{O}_{2}$ to give the desired $\mathrm{pO}_{2}$. For experiments with batch 6 with the whole soil-cores containing plants, evacuation was followed by replacing the atmosphere with previously prepared $\mathrm{Ar}-\mathrm{O}_{2}$ gas mixtures. Acetylene was injected to about 5 or $10 \%$ after removal of the corresponding volume of the gas phase. The procedure for soil cores was essentially as for the vials, except for batch 6 for which desiccators and vials were kept at $20^{\circ} \mathrm{C}$. All gas phases were initially at atmospheric pressure.

Ethylene was measured on I $\mathrm{ml}$ gas samples in a Perkin Elmer F I I Gas Chromatograph with a $2 \mathrm{~m} \times 0.003 \mathrm{~m}$ diam. column packed with 80 to Ioo mesh Poropak $\mathrm{N}$ at $90{ }^{\circ} \mathrm{C}, \mathrm{N}_{2}$ carrier gas and $\mathrm{H}_{2}$ flame ionization. Standard ethylene-argon gas mixtures were used for calibration, and readings from assay samples were corrected for ethylene contamination in the acetylene and, in time-course assays, for ethylene removed during previous samplings. Acetylene was also measured for all samples to provide a check on sampling errors. After assay, roots and rhizomes were washed and dried at $100{ }^{\circ} \mathrm{C}$; results were related to this dry weight unless otherwise stated.

Azotobacter paspali were counted either by the soil crumb or dilution method. 'Root 
Table I. Nitrogenase activity of roots of Paspalum notatum collected from different sites

$\begin{array}{lcc}\begin{array}{l}\text { Variety of } \\ P . \text { notatum }\end{array} & \text { Soil site } & \begin{array}{c}\text { Range of activity* } \\ \text { (nmol } \mathrm{C}_{2} \mathrm{H}_{4} / \mathrm{g} / \mathrm{h} \text { ) }\end{array} \\ \text { batatais } & \mathrm{A} & 3.5 \mathrm{I} \text { to } 7.16 \\ \text { pensacola } & \mathrm{A} & 0.05 \text { to } 0.54 \\ \text { batatais } & \mathrm{B} & 10.0 \text { to } 25.6 \\ \text { pensacola } & \mathrm{B} & 0.10 \\ \text { batatais } & \mathrm{C} & 20.8 \\ \text { batatais } & \mathrm{D} & 5.45 \\ \text { batatais } & \mathrm{E} & 1.04 \text { to } 22.0 \\ \text { batatais } & \mathrm{F} & 5.95 \\ \text { batatais } & \mathrm{G} & 2.28 \text { to } 3 \mathrm{I} \cdot 6 \\ \text { batatais } & \mathrm{H} & 16.3\end{array}$

* Maximum rates obtained, means of four replicate vials, $\mathrm{pO}_{2}$ varied from 0.01 to $0.05 \mathrm{~atm}$. Range obtained from batches I to 4 .

surface soil' was obtained by rubbing off the soil layer adhering to the roots with fingers, after removing by shaking 'rhizosphere soil' that occurred loose between the roots. After air-drying for $\mathrm{I} \mathrm{h}$, soils were sieved ( $\mathrm{I} \mathrm{mm}$ ) and $20 \mathrm{mg}$ subsamples scattered evenly over the surface of the agar medium. For the dilution counts, root surface soil was obtained by gently washing the roots. A dilution series $\left(\mathrm{IO}^{-2}, \mathrm{IO}^{-3}, \mathrm{IO}^{-4}\right)$ was prepared in tap water. One $\mathrm{ml}$ of each was mixed with $2 \mathrm{ml}$ of a $0.7 \%$ agar medium at $45^{\circ} \mathrm{C}$ and then poured on to a plate of the same medium solidified with $\mathrm{I} \cdot 5 \%$ agar. The nitrogen-free medium for both counting methods contained $\mathrm{K}_{2} \mathrm{HPO}_{4}, 0.005 \% ; \mathrm{KH}_{2} \mathrm{PO}_{4}, 0.015 \% ; \mathrm{MgSO}_{4} \cdot 7 \mathrm{H}_{2} \mathrm{O}, 0.02 \%$; $\mathrm{FeCl}_{3}, 0.00 \mathrm{I} \%$; $\mathrm{NaMoO}_{4} .2 \mathrm{H}_{2} \mathrm{O}, 0.0002 \%$; sucrose, $2 \%$; bromthymol blue, $5 \mathrm{ml} / 1$, of a $\mathrm{I} \%$ alcohol solution. The $\mathrm{pH}$ was adjusted to $6 \cdot 9 \pm 0 \cdot \mathrm{I}$. Organisms adhering to roots and rhizomes were counted after shaking pieces vigorously in water on a wrist-action shaker for 5 min and macerating briefly in an M.S.E. blender homogenizer. Growth of $A$. paspali, on plates incubated at $35^{\circ} \mathrm{C}$, appeared 2 days after inoculation as round, raised, dense colonies, which turned yellow because of dye absorption and acid production. Further details of the characterization of this organism were given in previous papers (Döbereiner, 1966; Döbereiner, 1970). Photomicrographs of $A$. paspali were taken with phase optics of living, unstained bacteria grown in shake cultures in nitrogen-free liquid medium.

Roots and rhizomes from some plants were fixed in acrolein, dehydrated, and embedded in glycol methacrylate (Feder \& O'Brien, I968). Sections (about $2 \mu$ m thick) were examined unstained with phase optics, or were stained in toluidene blue (Feder \& O'Brien, I968).

\section{RESULTS}

\section{Batch and sample variation}

Acetylene reduction by roots from Batches I to 4, where plant pieces were taken from the soil in Brazil, was slow during an initial lag period of at least I I $\mathrm{h}$ before the maximum rates were attained.

Table I shows that the activity of roots of Paspalum notatum cultivar 'batatais' differed both between sites, and between roots from the one site. In each batch roots of the Paspalum cultivar 'pensacola', which does not stimulate Azotobacter paspali in its rhizosphere, had insignificant activity. 
Table 2. Effect of incubation in different oxygen tensions on the lag period in subsequent acetylene reduction at $\mathrm{pO}_{2} 0.04 \mathrm{~atm}$

\begin{tabular}{|c|c|c|c|c|c|c|c|}
\hline \multirow[b]{2}{*}{ For $(h)$} & \multicolumn{2}{|c|}{$\begin{array}{l}\text { Incubation in } \\
\mathrm{pO}_{2} \mathrm{O} .00 \mathrm{~atm}\end{array}$} & \multicolumn{3}{|c|}{$\begin{array}{c}\mathrm{pO}_{2} \\
0.04 \mathrm{~atm}\end{array}$} & \multicolumn{2}{|c|}{$\begin{array}{c}\mathrm{pO}_{2} \\
0.20 \mathrm{~atm}\end{array}$} \\
\hline & 6 & 12 & I & 6 & 12 & 6 & I 2 \\
\hline Lag period (h) & 8 & 2 & 15 & 8 & 0 & 8 & 10 \\
\hline
\end{tabular}

\section{Oxygen tension and activity}

Preliminary experiments on batches $\mathrm{I}$ to 4 showed that the nitrogenase activity of roots was affected by oxygen tension, neither aerobic nor anaerobic atmospheres giving maximum activity. To examine the effect of oxygen on activity, roots and rhizomes from the soil cores of batch 5 were removed and placed in the assay vials in a glove box with a $\mathrm{N}_{2}$ atmosphere. The $\mathrm{N}_{2}$ atmosphere in the vials was then replaced by argon containing one of eight different $\mathrm{O}_{2}$ pressures (from o to $0.20 \mathrm{~atm}$ ). Acetylene was added and its reduction measured over a period of $36 \mathrm{~h}$. Activity, after the lag phase, was greatest at $\mathrm{pO}_{2}$ of $0.04 \mathrm{~atm}$; the $t$-test gave significant differences between $\mathrm{pO}_{2} 0.04$ and $\mathrm{pO}_{2} \mathrm{0} .0 \mathrm{I}$ and $0.06 \mathrm{~atm}$.

Even for these roots harvested under $\mathrm{N}_{2}$ there was a lag period of $\mathrm{I} 2$ to $20 \mathrm{~h}$, during which respiration would have diminished the $\mathrm{pO}_{2}$ within the vials so that maximum acetylene reduction probably coincided with $\mathrm{pO}_{2}$ values somewhat less than $0.04 \mathrm{~atm}$. Completely anaerobic atmosphere supported very little acetylene reduction, suggesting that facultative or obligate anaerobes were unimportant in nitrogen fixation. The long lag phase also indicates that blue-green algae were not a significant component of the material as they do not have a lag phase in activity; the vials were incubated in the dark, further restricting any algal contribution.

These results indicate that Azotobacter paspali associated with Paspalum notatum roots is most active in nitrogen fixation at a $\mathrm{pO}_{2}$ of about 0.04 atm. Nitrogenase activity of $A$. chroococcum cells grown under a $\mathrm{pO}_{2}$ of 0.09 atm follows a similar pattern and is similarly restricted by a $\mathrm{pO}_{2}$ of zero or $0.20 \mathrm{~atm}$. Carbon-limited cells are very sensitive to oxygen with maximum acetylene reduction at $\mathrm{pO}_{2}$ 0.0I to 0.05 atm (Dalton \& Postgate, 1969a; Drozd \& Postgate, 1970 b). Nitrogen fixation and acetylene reduction by $A$. vinelandii and $A$. chroococcum are more efficient in terms of sugar consumption at oxygen tensions less than 0.20 atm (Parker, 1954; Dalton \& Postgate, 1969a). Under aerobic conditions the extra energy is apparently consumed by increased respiration, thereby protecting the nitrogenase from damage by oxygen (Dalton \& Postgate, 1969a; Drozd \& Postgate, 1970b).

\section{Lag phase in nitrogenase activity}

The effect of $\mathrm{pO}_{2}$ on the lag phase in acetylene reduction was explored in two experiments. In the first, roots plus rhizomes from three cores of batch 6 were removed from the soil in a glove box under $\mathrm{N}_{2}$. The $\mathrm{N}_{2}$ in the vials was then replaced by $\mathrm{Ar} / \mathrm{O}_{2}$ mixtures and preincubated without acetylene for I, 6 or I $2 \mathrm{~h}$ at a $\mathrm{pO}_{2}$ of $0.20,0.04$ or $0 \mathrm{~atm}$. The atmosphere in the vials was then replaced by Ar plus 0.04 atm. $\mathrm{O}_{2}$ and acetylene added. Incubation at $\mathrm{pO}_{2} 0.04 \mathrm{~atm}$ for $6 \mathrm{~h}$ shortened the lag phase to 6 to $8 \mathrm{~h}$ and incubation for $\mathrm{I} 2 \mathrm{~h}$ eliminated the lag (Table 2). Thus acetylene itself did not cause the lag. Incubation without $\mathrm{O}_{2}$ was less effective in shortening the lag; after $\mathrm{I} 2 \mathrm{~h}$ incubation, activity increased gradually with maximum rates not attained until $\mathrm{I} 8 \mathrm{~h}$ after the $\mathrm{C}_{2} \mathrm{H}_{2}$ addition. Incubation in $\mathrm{pO}_{2} \mathrm{O} \cdot 20 \mathrm{~atm}$ both increased the length of the lag period and decreased the terminal rates.

Damage by oxygen thus probably accounts for the long lag phase and small nitrogenase 


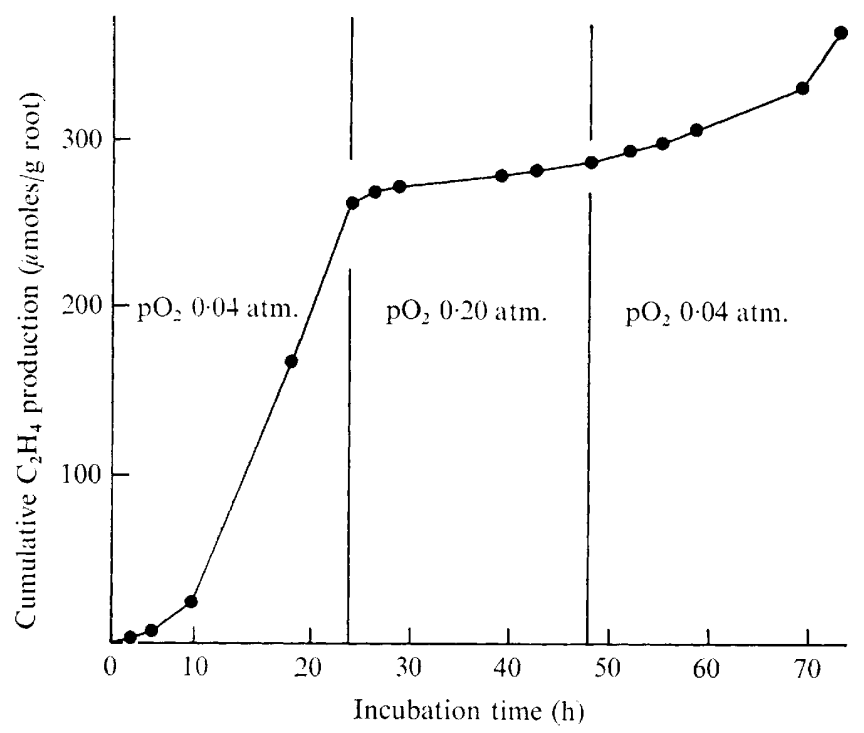

Fig. I. Effect of change of $\mathrm{pO}_{2}$ on nitrogenase activity. Paspalum notatum roots, extracted from soil cores of batch 6 anaerobically under $\mathrm{N}_{2}$, were incubated for $6 \mathrm{~h}$ without acetylene at $\mathrm{pO}_{2} 0.04 \mathrm{~atm}$. Acetylene reduction was then followed in an $\mathrm{Ar} / \mathrm{O}_{2}$ gas phase $\mathrm{pO}_{2} 0.04$ atm for $24 \mathrm{~h}$, then at $\mathrm{pO}_{2}$ 0.20 for $24 \mathrm{~h}$ and then returned to $\mathrm{pO}_{2} 0.04$ atm for $27 \mathrm{~h}$. Each point mean of samples from three replicate soil cores.

activity in the first experiments (batches $\mathrm{I}$ to 4 ) in which plants were taken from the soil in Brazil and the roots exposed to the air. But even roots extracted under $\mathrm{N}_{2}$ still showed a lag phase of some $\mathrm{I} 2 \mathrm{~h}$.

The second experiment examined the effect of changes in $\mathrm{pO}_{2}$ in the atmosphere on nitrogenase activity. Roots plus rhizomes from three soil cores of batch 6 were removed in a glove box under $\mathrm{N}_{2}$, and then incubated without acetylene in $\mathrm{Ar}$ with $0.04 \mathrm{~atm} \mathrm{O}_{2}$ for $6 \mathrm{~h}$. This atmosphere was then replaced by $\mathrm{Ar}$ with $0.04 \mathrm{~atm} \mathrm{O}_{2}$, acetylene added and nitrogenase assayed for $24 \mathrm{~h}$. The atmosphere was then again changed to $\mathrm{Ar}$ with $0.20 \mathrm{~atm} \mathrm{O}_{2}$ for a further $24 \mathrm{~h}$ and then back to one with $\mathrm{pO}_{2} 0.04 \mathrm{~atm}$. Some ethylene remained in the plant tissue even after evacuation and was gradually released into the atmosphere. No correction was made for this.

After an initial lag of $8 \mathrm{~h}$, a linear acetylene reduction was established in $\mathrm{pO}_{2} 0.04 \mathrm{~atm}$. This was immediately reduced on changing the atmosphere to $\mathrm{pO}_{2} \mathrm{O} \cdot 20$ atm with no subsequent change in rate over the $24 \mathrm{~h}$. Activity increased on return to an atmosphere of $0.04 \mathrm{~atm}$ after a lag phase lasting about $\mathrm{I} 2 \mathrm{~h}$, although the previous rates in the $\mathrm{pO}_{2} 0.04$ atm were not attained (Fig. I).

\section{Effect of $\mathrm{pO}_{2}$ on activity of intact soil cores with plants}

Two soil cores, with intact plants in metal cans open at both ends, from batch 6 were incubated in 21 desiccators in a glasshouse in Ar with 0.20 atm $\mathrm{O}_{2}$ and $5 \%$ acetylene. The two cores ( 1 and 2 ) reduced acetylene at similar, linear rates, with only a slight lag from adsorption and solution of the initially produced ethylene in the soil. After $24 \mathrm{~h}$, both desiccators were re-evacuated, core I regassed with Ar plus 0.04 atm $\mathrm{O}_{2}$ and core 2 with $\mathrm{Ar}$ plus $0.20 \mathrm{~atm} \mathrm{O}_{2}$. Both cores then continued to reduce acetylene at about the same rate (Fig. 2). 


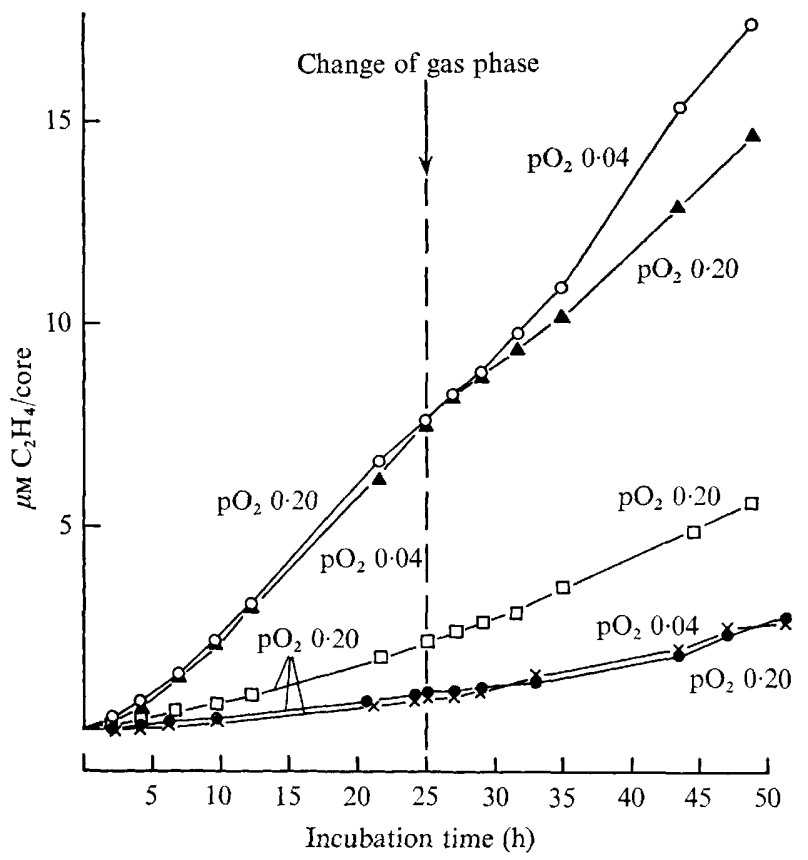

Fig. 2. Effect of oxygen tension on nitrogenase activity of Paspalum notatum plants, intact in soil cores, incubated in desiccators. The $\mathrm{Ar} / \mathrm{O}_{2}$ gas phase during assay for acetylene reduction was changed from $\mathrm{pO}_{2} 0.20$ to 0.04 and vice versa, or from $\mathrm{pO}_{2} 0.20$ to 0.20 atm. Incubation in a greenhouse with $\mathrm{I} 6 \mathrm{~h}$ day, temperature reaching a maximum of $35^{\circ} \mathrm{C}$ (cores $\mathrm{I},-\mathrm{C}-\mathrm{and} 2, \times-x$ ) or in a growth cabinet with a $\mathrm{I} 6 \mathrm{~h}$ day at constant temperature of $20^{\circ} \mathrm{C}$ (cores $3, \square-\square, 4 \boldsymbol{\Delta}-\boldsymbol{\Delta}$ and $6, \mathrm{O}-\mathrm{O})$.

These results were confirmed using cores 3,4 and 6 incubated intact in the desiccators in a Saxcil growth cabinet ( $\mathrm{I} 6 \mathrm{~h}$ day, light intensity $20000 \mathrm{~lx}$ at a constant temperature of $20^{\circ} \mathrm{C}$ ). The acetylene reduction rates were subsequently determined in different $\mathrm{O}_{2}$ atmospheres. As with cores $\mathrm{I}$ and 2, the external $\mathrm{pO}_{2}$ had little effect on nitrogenase activity (Fig. 2), the very small changes on altering the gas phase were not comparable with the drastic effects of $\mathrm{pO}_{2}$ observed for free roots.

Root respiration may reduce the oxygen tension at the root surface. Respiration of Sinapis alba roots embedded in agar developed an $\mathrm{O}_{2}$ gradient in the agar so that the $\mathrm{pO}_{2}$ at the root surface was about 0.05 atm, compared with the $\mathrm{pO}_{2}$ of the bulk agar of about $0.18 \mathrm{~atm}$ (Greenwood, 1971). Respiration by micro-organisms at the root surface would also help to maintain a small $\mathrm{pO}_{2}$.

The intact Paspalum notatum-Azotobacter paspali association in soil cores was well protected against oxygen even though some of the soils were sandy loams or almost pure sand (core 5). Extracting the roots from soil in some way disturbed the association and it took I $2 \mathrm{~h}$ to re-equilibrate with the new conditions. Possibly the lag represents an adjustment of the $A$. paspali cells to the assay $\mathrm{pO}_{2}$, but this is slower than the adjustment of nitrogenase activity of $A$. chroococcum cells grown in liquid culture to changes in $\mathrm{pO}_{2}$, which takes place within $0 . \mathrm{I}$ h (Drozd \& Postgate, I970 $b$; Yates, 1970). Alternatively the lag may reflect the effect of plant disturbance on root exudation. 
Table 3. Nitrogenase activity of components of the association of Paspalum notatum with Azotobacter paspali

Roots + surface soil

Rhizomes + surface soil

Roots + rhizomes + surface soil

Roots + rhizomes (washed)

Root surface soil

Rhizosphere soil $\mathrm{nmol}$
$\mathrm{C}_{2} \mathrm{H}_{4} / \mathrm{g} / \mathrm{h}$

$6 \cdot 44^{*}$

$2 \cdot 44$

$8 \cdot 53$

$7 \cdot 60$

$0 \cdot 180$

0.072

$\begin{array}{cc}\text { per g root } & \text { A. paspali } \times 10^{2} \\ 204 \dagger & \text { per g soil } \\ 130 & 298 \\ - & 501 \\ 136 & - \\ 115 & - \\ - & 226 \\ & 26\end{array}$

* Maximum rates obtained, mean of four replicate vials, assay $\mathrm{pO}_{2} 0.04 \mathrm{~atm}$.

$\dagger$ Dilution count, numbers expressed per $\mathbf{g}$ root (or rhizome) or per $\mathbf{g}$ associated soil.

Table 4. Effect of sucrose addition on nitrogenase activity and numbers of Azotobacter paspali in root-free soil collected from under Paspalum notatum plants

\begin{tabular}{|c|c|c|c|c|}
\hline Sucrose & $\begin{array}{l}\text { Incubation } \\
\mathrm{pO}_{2} \text { (atm) }\end{array}$ & $\begin{array}{c}\text { A. paspali/g } \\
\text { dry soil } \\
\text { (dilution count) }\end{array}$ & $\begin{array}{l}\text { A. paspali micro- } \\
\text { colonies/g dry soil } \\
\text { (soil crumb method) }\end{array}$ & $\begin{array}{c}\mathrm{C}_{2} \mathrm{H}_{4} \text { production } \\
\text { nmoles } / \mathrm{g} / \mathrm{h}\end{array}$ \\
\hline $\begin{array}{l}0 \\
1 \cdot 3 \%\end{array}$ & & ls before incubat & $\begin{array}{l}\mathrm{I} 240^{*} \\
1600\end{array}$ & \\
\hline \multicolumn{5}{|c|}{ After $72 \mathrm{~h}$ of incubation with $5 \% \mathrm{C}_{2} \mathrm{H}_{2}$} \\
\hline 0 & 0.04 & IIOO & I 440 & $0.005 \dagger$ \\
\hline $1 \cdot 3 \%$ & 0.04 & 823 & 1600 & $8 \cdot 59$ \\
\hline 0 & $0 \cdot 20$ & - & 1320 & 0.005 \\
\hline $1 \cdot 3 \%$ & $0 \cdot 20$ & I 230 & 2110 & $8 \cdot 40$ \\
\hline \multicolumn{5}{|c|}{ * Mean for 2 replicates. $\quad+$ Maximum linear rates. } \\
\hline
\end{tabular}

Plants from batches 4 and 6 were dissected into several components and their ability to reduce acetylene measured at $\mathrm{pO}_{2} 0.04$ atm. Table 3 shows that the activities of separated roots and rhizomes of batch 4 were less than those of roots attached to rhizomes. Gentle washing of the roots decreased the activity only slightly, although it removed about half the Azotobacter paspali cells, indicating that the cells closest to the root surface were the most active. Soil, even though not completely free from fine roots, had only a hundredth the activity of roots. Azotobacter paspali were fewer in the rhizosphere than in the root-surface soil (Table 3). Numbers in root-surface soil were similar to those on washed roots plus rhizomes (on a dry weight root basis), although the nitrogenase activities were very different.

Similar results were obtained with roots plus rhizomes from the soil cores of batch 6 when activity of the same root pieces was measured before and after washing. Activity of the untreated root pieces varied considerably ( 17.9 to $3 \mathrm{I} .8 \mathrm{nmol} \mathrm{C}_{2} \mathrm{H}_{4} \mathrm{~h} / \mathrm{g}$ ), and most was closely associated with the roots; even vigorous washing under a strong jet of tapwater until no soil was visible removed only half of the activity.

Possibly counting methods underestimated the total numbers of Azotobacter paspali present on the root surface. Azotobacter chroococcum are sensitive to shaking and dilution procedures (Billson, Williams \& Postgate, 1970). Single organisms of $A$. paspali might similarly fail to form colonies on aerobically incubated agar plates after being vigorously dispersed. Numbers obtained by dilution counts resembled those by the soil crumb method (Tables 3, 4), whether tapwater, or mineral salt solution, as suggested by Billson et al. (1970), 

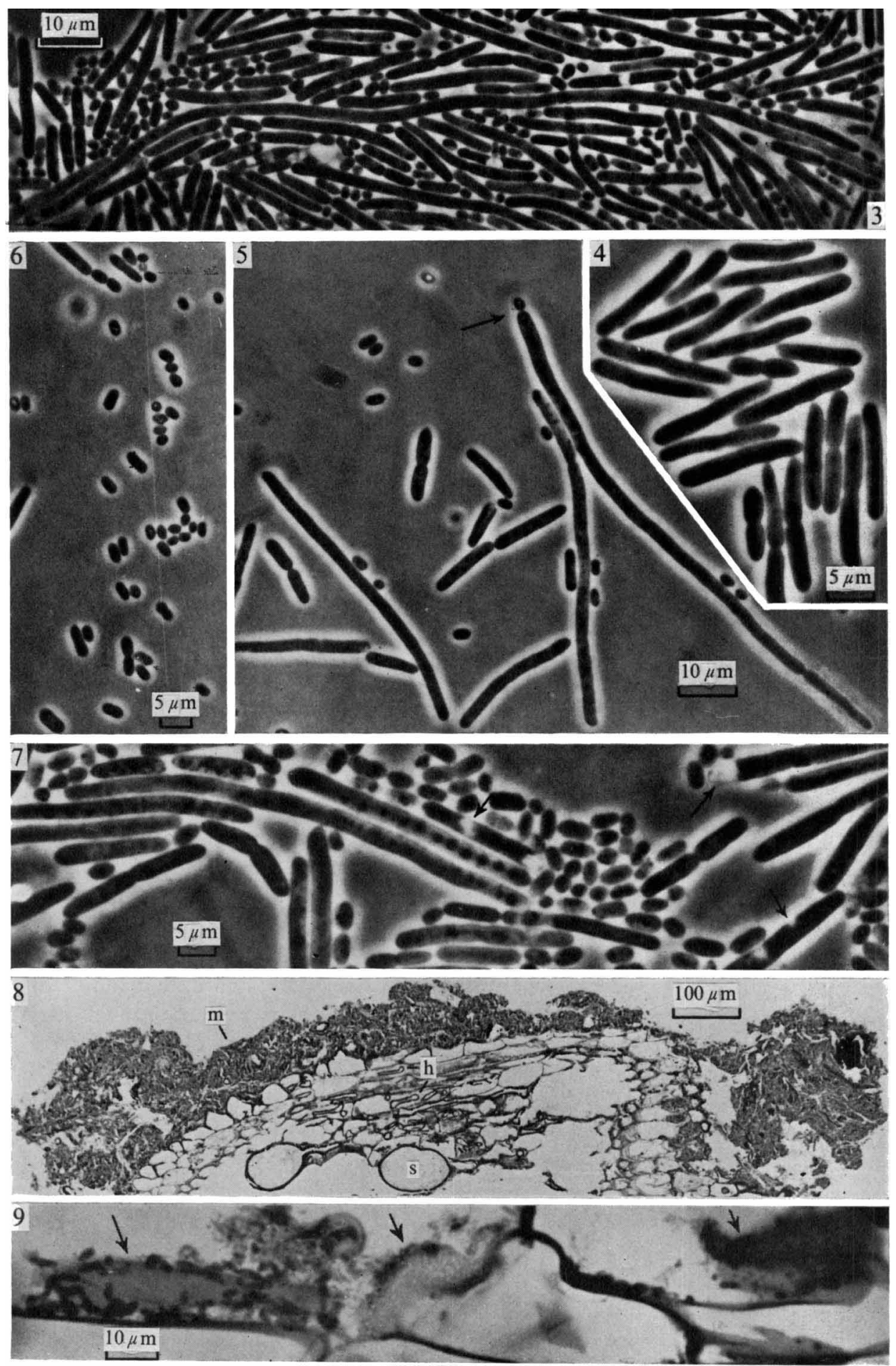
was used for dilution (Kass, I970). Were only microcolonies of $A$. paspali counted, this would partly account for the apparent difference in relative activity between soil and roots. Alternatively, root-surface cells may be more active because there is more energy for nitrogenase activity at the root surface; the increase in activity after adding sucrose to soil supports this idea.

These various factors may operate concurrently; certainly, the numbers of nitrogen-fixing organisms counted by the usual techniques do not correlate well with nitrogenase activity.

Thin sections show that field-grown Paspalum notatum 'batatais' roots with nitrogenase activity have a prominent mucigel layer, which stained a metachromatic red with toluidene blue. Colonies of bacteria, some with very large cells, occurred on the root surface associated with the mucigel which might provide the right condition for fixing nitrogen and also protect the cells from being washed off the roots. The roots also had an Endogone mycorrhizal association (Fig. 8, 9). Neither a mucigel layer nor microcolonies of bacteria were found on $P$. notatum 'pensacola' roots.

\section{Identification of Azotobacter paspali}

Azotobacter paspali was the only organism able to fix nitrogen isolated in any numbers from the root and rhizome surfaces of our plants, and we have assumed that it was responsible for the associated nitrogenase activity. Azotobacter paspali isolated from Paspalum notatum 'batatais' roots has distinctive forms in pure culture (Döbereiner, 1966) that make it easy to identify (Fig. 3 to 7 ). Shortly after subculture, very long (up to $130 \mathrm{~nm}$ ) rods predominate, which in liquid shake-culture divide to form rods 7 to $10 \mathrm{~nm}$ long. Coccoid bacteria resembling those usual in other Azotobacter species are then formed. Many contain prominent inclusion granules.

\section{Nitrogenase activity in soil}

The dependence of nitrogenase activity of Azotobacter paspali on available energy was studied by adding sucrose to soil. Soil from cores of batch 5 was shaken free from large plant pieces and air-dried just enough to be sieved through a $\mathrm{I} \mathrm{mm}$ mesh screen to remove all fine roots. A sterile $10 \%$ sucrose solution $(20 \mathrm{ml})$ in tapwater was then added to $150 \mathrm{~g}$ soil and thoroughly mixed by hand. The crumb structure of the soil was retained by this amount of moisture, which gave a final sucrose concentration in soil of $I \cdot 3 \%(\mathrm{~W} / \mathrm{W}$ moist soil). A control soil sample was treated similarly with sterile tapwater without sucrose. Samples of about Io $\mathrm{g}$ dry wt soil were then placed in McCartney vials, the vials evacuated and the atmosphere replaced with Ar plus 0.04 or 0.20 atm $\mathrm{O}_{2}$, and incubated with $10 \%$

Fig. 3 to 9. Azotobacter paspali from shake cultures of nitrogen-free medium. Phase contrast of living cells.

Fig. 3. Six-day culture showing range of cell types, from characteristic long cells to cocci. Many cells contain prominent inclusion granules.

Fig. 4. One-day culture. Cells of intermediate length predominate.

Fig. 5. Three-day culture with coccoid forms now present (formed by budding from long cells? See arrow).

Fig. 6. Six-day culture with coccoid forms predominating.

Fig. 7. Three-day culture. Many cells have prominent inclusion granules and some have clear areas (arrows) which sometimes disappear.

Fig. 8. Oblique longitudinal section of field grown Paspalum notatum root showing prominent mucigel layer $(\mathrm{m})$, and hyphae $(\mathrm{h})$ and spores (s) of Endogone.

Fig. 9. Epidermis of field-grown Paspalum notatum root showing microcolonies of bacterial cells (arrows) on the surface. 
Table 5. Comparison of nitrogenase activity of the intact Paspalum notatum-Azotobacter paspali system in soil cores with the activity of the different components

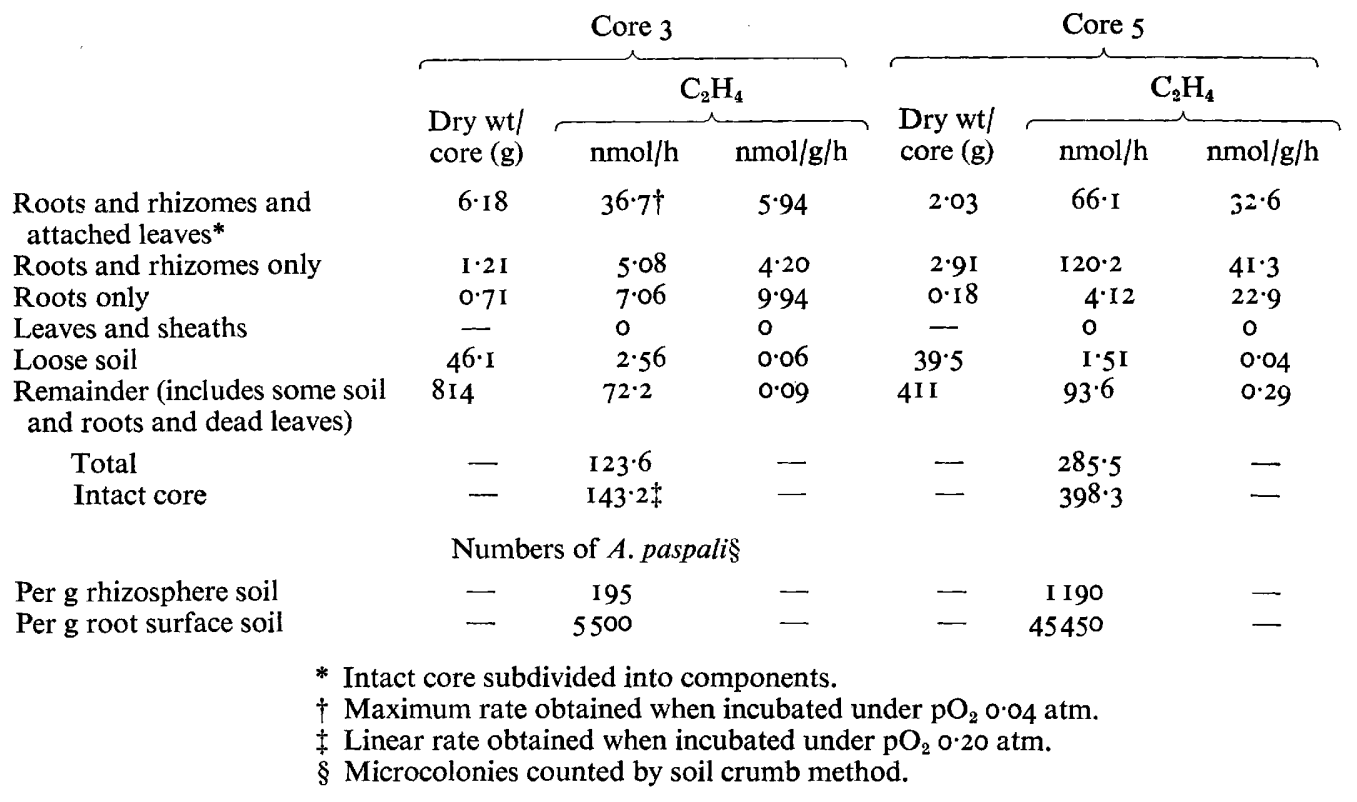

acetylene at $20^{\circ} \mathrm{C}$. Azotobacter paspali were counted in the samples before and after incubation, by the soil-crumb method. Table 4 shows that adding sugar to the soil stimulated nitrogenase activity and the soil without sugar remained inactive, suggesting that $A$. paspali in the soil is carbon-limited. This activity seemed not to reflect multiplication of $A$. paspali, as numbers of microcolonies were similar before and after incubation. Because the atmosphere lacked nitrogen, protein synthesis dependent on nitrogen fixation would be minimal. There was little effect of $\mathrm{pO}_{2}$ on the nitrogenase activity, possibly because the extra energy supply enabled the cells under $\mathrm{pO}_{2} \mathrm{O} \cdot 20 \mathrm{~atm}$, after a short lag, to respire faster and this protected the nitrogenase from $\mathrm{O}_{2}$.

\section{Nitrogenase activity of intact plant-soil cores}

Two soil cores ( 3 and 5 ) from batches 5 and 6 were used to compare nitrogenase activity of the intact system with that of its component plant and soil parts. The intact cores were incubated in the light at $20{ }^{\circ} \mathrm{C}$ under air with $10 \%$ acetylene, in desiccators, and a linear rate of activity established. The cores were then dissected into components which were placed in McCartney vials, the vials evacuated and the atmosphere replaced with Ar plus 0.04 atm $\mathrm{O}_{2}$ and $10 \%$ acetylene. The vials were incubated at $20{ }^{\circ} \mathrm{C}$ and sampled until the activity was maximal.

Table 5 compares the contribution of the components with the intact Paspalum system. Leaves and leaf sheaths did not reduce acetylene, and roots and rhizomes reduced most. Roots and rhizomes of core 5 were 6 to ro times as active as those of core 3, demonstrating the differences in activity between samples. The soils from both cores had the same relatively small activity, possibly because some small roots were not separated from the soil. In two other cores ( $\mathrm{I}$ and 4 ) where the soil was lighter and the roots could be more completely separated, the soil was inactive (see also Table 4). 


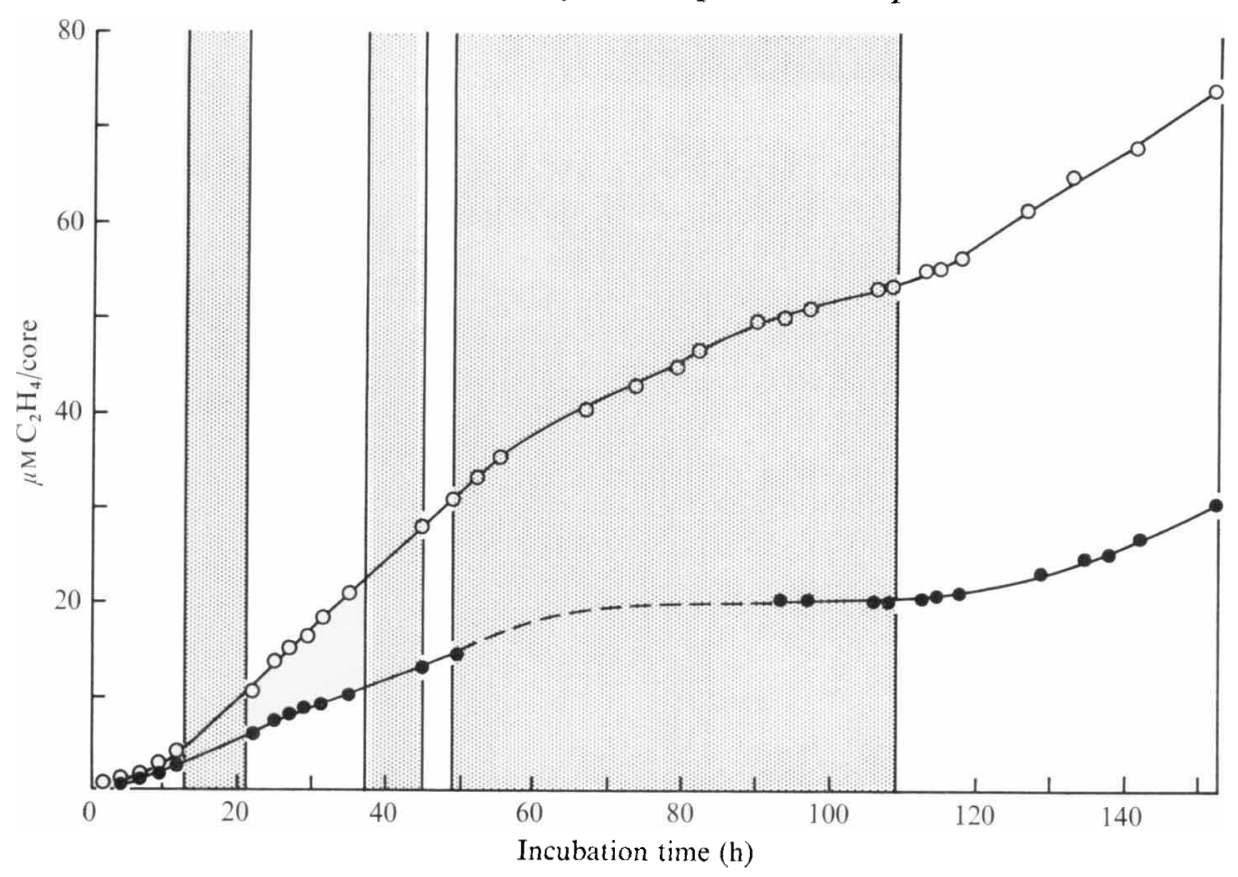

Fig. Io. Effect of light on nitrogenase activity of intact plants of Paspalum notatum in soil cores 4 and 6. Cores incubated in desiccators under air with $10 \%$ acetylene, at constant temperature of $20{ }^{\circ} \mathrm{C}$ in a growth cabinet, light intensity $20000 \mathrm{~lx}$. Hatching represents dark periods. Core 4 without acetylene from 50 to $90 \mathrm{~h}(-)$.

Both intact soil cores had greater nitrogenase activities than the sum of their component parts. This indicates that the maximum rates obtained in our assays for roots plus rhizomes were closest to the rates of nitrogenase activity in the intact system, but that even these are smaller.

\section{The effect of light on nitrogenase activity of intact cores containing plants}

Two soil cores from batch 6 were incubated in air containing $10 \%$ acetylene in a Saxcil growth cabinet ( $16 \mathrm{~h}$ day, $20000 \mathrm{~lx}, 20^{\circ} \mathrm{C}$ constant temperature). Acetylene reduction was linear and unaffected by day/night changes (Fig. IO), again indicating that blue-green algae play a minor role (if any) in the nitrogen fixation of these cores. The dark period was then extended to $60 \mathrm{~h}$. After $45 \mathrm{~h}$ nitrogenase activity had almost ceased for core 4 and was much diminished for the more active core 6 . When the cores were returned to the light, nitrogenase activity increased within the first hours, returning almost to the original rates after $15 \mathrm{~h}$. These results suggest that the original day/night cycle provided enough root exudates to maintain $\mathrm{N}_{2}$ fixation during the night.

Core 4 with less nitrogenase activity, when examined at the end of the experiment, contained mostly entire plants $(4.5 \mathrm{~g}$ dry wt roots plus rhizomes with leaves attached, $0.9 \mathrm{~g}$ without leaves), whereas in core 6 only half the plants had leaves $(3.0 \mathrm{~g}$ of roots plus rhizomes attached to leaves, $3.5 \mathrm{~g}$ without leaves). The rhizome pieces without leaves would not depend on photosynthesis for substrate to support nitrogenase activity and this may have accounted for the smaller effect of the long dark period on core 6 .

Nitrogenase activity associated with Paspalum roots is thus indirectly related to photosynthesis. Paspalum notatum is a plant that, once established, dominates a sward in open 
sunlight, but is readily substituted by other species in shade. Shading an established lawn of $P$. notatum diminished the number of associated Azotobacter paspali (Döbereiner \& Campelo, 1971).

Many tropical grasses, including Paspalum, synthesize $\mathrm{C}_{4}$-dicarboxylic acids as the initial product of photosynthesis (Hatch \& Slack, 1970), and have higher light saturation values, and faster maximum rates of photosynthesis than plants with the $\mathrm{C}_{\mathbf{3}}$-Calvin cycle photosynthesis pathway, enabling the intense radiation in the tropics to be used efficiently (Cooper, 1970). Because little of the fixed carbon is used in photorespiration by these $C_{4}$ plants, more of the photosynthate may be directed to root growth and exudation, and be responsible for the observed rhizosphere stimulation of free-living nitrogen-fixing bacteria (Döbereiner \& Campelo, 197I). Sugar cane, Pennesitum purpureum, Panicum maximum, Cynbopogon citratus, Paspalum notatum 'batatais', Zea mays and rice are plants found to fix significant amounts of nitrogen in the rhizosphere (Rinaudo, 1970; Weinhard et al. 1971 ; Döbereiner, Day \& Dart, 1972) and all except rice are $\mathrm{C}_{4}$ plants.

\section{DISCUSSION}

The soil cores gave considerable nitrogen fixation when extrapolated to larger areas. On a surface area basis, and using the theoretical ratio of ${ }_{3} \mathrm{C}_{2} \mathrm{H}_{4} \boxminus \mathrm{IN} \mathrm{N}_{2}$ (Hardy, Holsten, Jackson \& Burns, 1968), cores 3 and 6 gave presumptive $\mathrm{N}_{2}$ fixation rates of 15 and $4 \mathrm{I} \mathrm{kg}$ $\mathrm{N} /$ ha/year. Core 5, which also had the biggest plants, gave a value of $93 \mathrm{~kg} \mathrm{~N} / \mathrm{ha} /$ year.

An extrapolation can also be made on the basis of root plus rhizome wt/surface area of soil. Four areas of Paspalum notatum $25 \times 31 \mathrm{~cm}$ sampled in Brazil gave a mean value of I $200 \mathrm{~kg} /$ ha dry wt of roots plus rhizomes. Cores 3,6 and 5 contained 8. I I, 5.07 and 7.03 $\mathrm{g}$ dry wt of roots and rhizomes, corresponding to nitrogen fixation of 16,72 and $117 \mathrm{~kg}$ $\mathrm{N} /$ ha/year respectively. Considering that the tops of the plants in the cores had been clipped before sampling, and that they had been disturbed by sampling and travel to England, these values for $\mathrm{N}$ fixed are probably not an overestimate.

This amount of nitrogen fixation would suffice for the growth requirements of Paspalum notatum in the field and is consistent with its ability to establish an extensive cover on poor sandy soils without any $\mathbf{N}$ fertilizer. Because it produces little dry matter and is not readily eaten by cattle, it is not an economically important variety. Other improved, hairless cultivars, including 'pensacola', are narrow leaved and widely used as pasture grasses. Most of these types are diploid and cross readily (G. W. Burton, personal communication); the cultivar 'batatais' is tetraploid and apomyctic and rarely if ever crosses (Burton, I948), so has not been used for breeding.

Future breeding programmes with tropical grasses should take into account the potential capacity for stimulating nitrogen-fixing organisms in their rhizosphere.

Johanna Döbereiner is indebted to the British Overseas Development Administration and The Brazilian National Research Council for the Research Fellowship at Rothamsted. She was on leave from the Instituto de Pesquisas e Experimentacao Agropecuarias Centro Sul, Rio de Janeiro, Brazil. J. M. Day is grateful to the Luton County Borough Council for a Postgraduate Fellowship. We thank Dr B. Tregunna and Dr J. V. Lake for discussions on photosynthesis in grasses, Dr B. Mosse for identifying Endogone, and Muriel Chandler for sectioning the roots. 


\section{REFERENCES}

ABD-EL-MALEK, Y. (197I). Free living nitrogen fixing bacteria in Egyptian soils and their possible contribution to soil fertility. In Biological Nitrogen Fixation in Natural and Agricultural Habitats. Plant and Soil, special volume, pp. 423-442. Edited by T. A. Lie \& E. G. Mulder. The Hague: Nÿhoff.

Billson, S., Williams, K. \& Postgate, J. R. (1970). A note on the effect of diluents on determination of viable numbers of Azotobacteriaceae. Journal of Applied Bacteriology 33, 270-273.

Brouzes, R., MAYFIELD, C. I. \& KNOWLes, R. (I97I). Acetylene and $\mathbf{N}^{15}$ studies in agricultural and forest soils: effect of oxygen partial pressure on nitrogen fixation and acetylene reduction in a sandy loam soil amended with glucose. In Biological Nitrogen Fixation in Natural and Agricultural Habitats. Plant and Soil, special volume, pp. 481-494. Edited by T. A. Lie \& E. G. Mulder. The Hague: Nÿhoff.

Burton, G. W. (1948). The method of reproduction in common Bahia grass Paspalum notatum. Journal of the American Society of Agronomy 40, 443-452.

COOPER, J. P. (1970). Potential production and energy conversion in temperate and tropical grasses. Herbage Abstracts 40, I-I 5 .

Dalton, H. \& Postgate, J. R. (1969a). Effect of oxygen on growth of Azotobacter chroococcum in batch and continuous cultures. Journal of General Microbiology 54, 463-473.

Dalton, H. \& Postgate, J. R. (1969b). Growth and physiology of Azotobacter chroococcum in continuous culture. Journal of General Microbiology 56, 307-319.

DöBEREINER, J. (1966). Azotobacter paspali sp.n. uma bacteria fixadora de nitrogenio na rizosfera de Paspalum. Pesquisa Agropecuaria Brasileira 1, 357-365.

Döbereiner, J. (1968). Non-symbiotic nitrogen fixation in tropical soils. Pesquisa Agropecuaria Brazileira $3, \mathrm{I}-6$.

DöBEREINER, J. (1970). Further research on Azotobacter paspali and its variety specific occurrence in the rhizosphere of Paspalum notatum Flügge. Zentralblatt für Bakteriologie, Parasitenkunde (Abteilung 2) 124, 224-230.

Döbereiner, J. \& CAMPelo, A. B. (I97I). Non-symbiotic nitrogen fixing bacteria in tropical soils. In Biological Nitrogen Fixation in Naturaland Agricultural Habitats. Plant and Soil, special volume, pp. 457470. Edited by T. A. Lie \& E. G. Mulder. The Hague: Nÿhoff.

DöBereiner, J., DAY, J. M. \& DART, P. J. (1972). Nitrogenase activity in the rhizosphere of sugar cane and some other tropical grasses. Plant and Soil, (in the press).

Drozd, J. \& PostGate, J. R. (1970a). Interference by oxygen in the acetylene reduction test for aerobic nitrogen-fixing bacteria. Journal of General Microbiology 60, 427-429.

DrozD, J. \& Postgate, J. R. (1970b). Effects of oxygen on acetylene reduction, cytochrome content and respiratory activity of Azotobacter chroococcum. Journal of General Microbiology 63, 63-73.

Feder, N. \& O’Brien, T. P. (1968). Plant microtechnique: some principles and new methods. American Journal of Botany 55, I23-I42.

GreENWOOD, D. J. (1971). Studies on the distribution of oxygen around the roots of mustard seedlings (Sinapis alba L). New Phytologist 70, 97-101.

Hardy, R. W. F., Holsten, R. D., JaCkson, E. K. \& Burns, R. C. (1968). The acetylene-ethylene assay for $\mathrm{N}_{2}$ fixation: laboratory and field evaluation. Plant Physiology 43, I I85-I 207.

Hatch, M. D. \& SlaCK, C. R. (1970). Photosynthetic $\mathrm{CO}_{2}$-fixation pathways. Annual Review of Plant Physiology 2I, I4I-I62.

KASS, D. C. (1971). Sources of nitrogen in tropical environments with special reference to the relationship between Paspalum notatum Flügge and Azotobacter paspali Döbereiner. M.S. Thesis, Cornell Unjversity, Ithaca, New York.

Kass, D. C., Drosdoff, M. \& AleXANDer, M. (1971). Nitrogen fixation by Azotobacter paspali in association with Bahia grass (Paspalum notatum). American Society for Soil Science Proceedings 35, 286-289.

Pacewiczowa, T. H., Balandreau, J. \& Dommergues, Y. (1970). Fixation microbienne de l'azote dans un sol salin tunesian. Soil Biology and Biochemistry 2, 47-53.

PARKER, A. C: (1954). Effect of oxygen on the fixation of nitrogen by Azotobacter. Nature, London I73, 780-781.

Parker, C. A. \& Scutt, P. B. (1960). The effect of oxygen on nitrogen fixation by Azotobacter. Biochimica et biophysica acta $38,230-238$.

Rinaudo, G. (1970). Fixation biologique de l'azote dans trois types de sols de rizières de cote d'Ivoire. These de Docteur Ingeniuer, Faculté des Sciences, Montpellier. 
Rinaudo, G., Balandreau, J. \& Dommergues, Y. (1971). Algal and bacterial non-symbiotic nitrogen fixation in paddy soils. In Bacterial Nitrogen Fixation in Natural and Agricultural Habitats. Plant and Soil, special volume, pp. 471-479. Edited by T. A. Lie \& E. G. Mulder. The Hague: Nÿhoff.

Steyn, P. L. \& Delwiche, C. C. (1970). Nitrogen fixation by non-symbiotic microorganisms in some California soils. Environmental Science and Technology 4, I $122-1128$.

Weinhard, P., !Balandreau, J., Rinaudo, G. \& Dommergues, Y. (1971). Fixation non-symbiotique de l'azote dans la rhizosphere de quelques non-legumineuses tropicales. Revue d'ecologie et de biologie du sol 8, 367-373.

YATES, M. G. (1970). Control of respiration and nitrogen fixation by oxygen and adenine nucleotides in $\mathrm{N}_{2}$-grown Azotobacter chroococcum. Journal of General Microbiology 60, 393-40I.

Yoshida, T. \& ANCAJAS, R. R. (1971). Nitrogen fixation by bacteria in the root zone of rice. Soil Science Society of America Proceedings 35, I56-157. 